\title{
The Effect of Reproductive Health Gymnastics on Hemoglobin Levels of Female Adolescents
}

\author{
Bahrah Bahrah ${ }^{1}$, Ariani Pongoh ${ }^{1}$, Yuni Subhi Isnaini ${ }^{1}$, Anwar Mallongi ${ }^{1}$, Dian Puji Lestari ${ }^{2}$ \\ ${ }^{1}$ Lecturers of Poltekkes Kemenkes Sorong, Indonesia, ${ }^{2}$ Professor of Environmental Health Department, \\ Faculty of Public Health, Hasanuddin University, Makassar.
}

\begin{abstract}
Female adolescents who have experienced menstruation are at high risk of anemia, especially iron nutritional anemia. Efforts made by the Government in overcoming anemia in adolescent girls are by providing Blood Plus Tablets, but based on data from the Ministry of Health in 2017, the percentage of Fe (iron) tablets obtained by adolescent girls is still very low, namely $13.8 \%$, so it is not yet fulfilling. the national target is $30 \%$, so there needs to be another strategy to overcome anemia in adolescent girls. Reproductive health exercise is one of the physical activities that can be an alternative for adolescent girls who experience anemia because it can increase hemoglobin production. This study analyzed the hemoglobin levels of adolescent girls after being given reproductive health exercises. The results showed that Kespro exercise had an effect on hemoglobin levels in adolescent girls with a $\mathrm{p}$ value $<\alpha(0.05)$ where the hemoglobin level before being given treatment in the intervention group was the average hemoglobin level of $10.1 \mathrm{gr} / \mathrm{dL}$ and the hemoglobin level after treatment. That is, the average hemoglobin level is $13 \mathrm{gr} / \mathrm{dL}$. The hemoglobin level before being given the treatment in the control group was an average hemoglobin level of $9.8 \mathrm{gr} / \mathrm{dL}$ and the hemoglobin level after being given the treatment was an average hemoglobin level of $12.2 \mathrm{~g} / \mathrm{dL}$.
\end{abstract}

Keywords: Female Adolescents, Hemoglobin Levels, Anemia, Reproductive Health Gymnastics.

\section{Introduction}

Adolescence is a period of change that occurs during childhood into adulthood which is marked by changes in growth and development. One of the developments that occurs during adolescence is that it begins with the maturation of reproductive organs such as menstruation in young women. Menstruation or menstruation is periodic bleeding through the vagina with endometrial discharge that occurs for 3-7 days with blood output of about 50-150 milliliters ${ }^{1}$.

Physiologically, girls who experience menstruation will bleed every month. Excessive bleeding and irregular menstrual cycles can affect the condition of young women ${ }^{2}$. Teenage girls who have experienced

\section{Corresponding Author:}

\section{Bahrah Bahrah}

Lecturers of Poltekkes Kemenkes Sorong, Indonesia e-mail: bahrahbahrah42@gmail.com menstruation are at high risk of anemia, especially iron nutritional anemia.

Anemia is a hemoglobin $(\mathrm{Hb})$ level or the number of red blood cells that is less than normal ( $12.0 \mathrm{gram} / 100 \mathrm{ml})$. Signs and symptoms of adolescents who have anemia such as pale, weak, tired, dizzy, which causes the ability to concentrate on learning to decline, inhibits physical growth and development of brain intelligence, and decreases in immune system due to increased infectious diseases $^{3-8}$.

Based on data from the WHO (World Health Organization) in the SEARO (South East Asian Region Office) in $2014^{9}$, young women suffering from mild to severe anemia in Southeast Asia range from 25-40\%, while in developing countries women suffer from substance deficiency anemia as much as 370 million with $41 \%$ of non-pregnant women and girls in India the prevalence of anemia reaches $45 \%$. In addition, the prevalence of anemia in Indonesia is still quite high. Based on the results of the 2018 Riskesdas data, the 
prevalence of anemia that occurs in women is $27.2 \%$ with the proportion aged $15-24$ years of $32 \%{ }^{10}$.

Efforts made by the government in overcoming anemia in adolescent girls are by providing Blood Plus Tablets in schools such as Junior High Schools (SMP) and Senior High Schools (SMA) or the equivalent given the dosage of 1 tablet/week and 1 tablet/day during menstruation ${ }^{11}$. Based on data from the Ministry of Health in 2017, the percentage of Fe (iron) tablets obtained by adolescent girls is still very low, namely $13.8 \%$, so that it has not met the national target of $30 \%$, for this we need another strategy to overcome anemia in adolescents. ${ }^{11-14}$

One of the strategies that can be done to overcome the problem of anemia is by providing therapy in the form of physical activity. Doing physical activity can increase blood volume caused by cardiovascular changes (Nurafandi, 2017). Individuals who exercise regularly will experience a slight increase in hemoglobin, this is because cells or tissues need more $\mathrm{O} 2$ (oxygen) when doing activities ${ }^{15-17}$.

Increased oxygen consumption during physical activity allows hemoglobin which carries protein in erythrocytes to reach cells. An important function of hemoglobin is as a medium for transporting oxygen from the lungs (respiratory organs) throughout the body. Physical activity is an activity that can improve health status if it is done regularly, routinely and repeatedly. Physical activity that is in great demand by young women is gymnastics ${ }^{18,19}$. One of the exercises that teenagers can do to increase their hb level is by doing reproductive health exercises. Reproductive health exercise is a physical exercise adopted from aerobics and SKJ (Physical Fitness Exercises) in 2012 which requires sufficient oxygen to get a source of energy (Sarah et al., 2019). Based on research conducted by Sarah in the intervention group which was carried out for 4 weeks by being given $\mathrm{Fe}$ tablets and reproductive health exercises with a duration of 15-20 minutes 3 times a week. There was an increase in hemoglobin levels from an average of $10.43 \mathrm{gr} / \mathrm{dL}$ to $13.98 \mathrm{gr} / \mathrm{dL}$, thus the effect of reproductive health exercise on adolescent hemoglobin levels at SMP 26 Semarang in $2019^{19}$.

\section{Materials and Method}

This research is a type of experimental Quasy research with a pre-post test control group design. This research was conducted in the Work Area of the Sowi
Manokwari Health Center, Indonesia. This study used 2 groups where the control group was given reproductive health exercise without intervention and the intervention group was given reproductive health exercise.

The population in this study were girls aged 13-15 years in the work area of the Sowi Manokwari Health Center in 2020. The sample of this study was anemic girls aged 13-15 years who met the inclusion criteria. The sampling method in this study is nonprobability sampling with purposive sampling technique, namely sampling with the determination of researchers based on inclusion criteria. The number of samples in this study were 20 people.

Reproductive health exercise that is implemented is a development of reproductive health exercise products that have been validated by experts through small-scale validity and reliability tests, product testing and product revisions after small-scale trials to produce products. The product for the development of reproductive health exercise was carried out by Sarah in 2019. The reproductive health exercise movement will be observed using a reproductive health exercise guide.

In this study, data sources were obtained from secondary and primary data. Secondary data were used for a preliminary study to determine the prevalence of anemia in junior high schools in Manokwari Regency. Primary data is by collecting data directly to respondents. The research flow, namely: carrying out the research permit procedure, the research will be assisted by the enumarator, namely by selecting the enumerator. Prepare research instruments and equipment needs for research.

Young women who have agreed to be sampled need to fill out an informed consent form. In examining hemoglobin levels with the cyanmethemoglobin method by taking 20 ul capillary blood to find anemic adolescent girls who meet the inclusion and exclusion criteria that have been determined previously. After finding the young women who had mild dysmenorrhea and anemia who met the criteria to be sampled. Provide an explanation of the objectives, benefits, risks and research procedures to anemic adolescent girls.

Researchers provide education about anemia in young women and alternative treatments by doing reproductive health exercises. Hemoglobin levels were checked before intervention, during menstruation and after intervention with the cyanmethemoglobin method. 
The intervention group was female adolescents with anemia aged 13-15 who received reproductive health exercises, where the first week of menstruation was carried out 5 times a week and in the following week after menstruation was carried out 3 times a week with a duration of 15-20 minutes and administration of $\mathrm{Fe} 60$ tablets. mg as much as 30 tablets.

The control group was anemic adolescent girls aged 13-15 years who only received 30 tablets of $\mathrm{Fe} 60 \mathrm{mg}$ for 4 weeks. After being given the intervention for 4 weeks, a re-assessment will be carried out by taking $20 \mathrm{ul}$ of blood for the hemoglobin level which will be checked by the cyanmethemoglobin method using a photometer. Assessment of planned hemoglobin levels will be carried out by the researcher himself and assisted by the enumerator. After each treatment got the final result of the measurement, the researchers made a comparison, namely which intervention group experienced changes in hemoglobin levels. Furthermore, data processing and analysis are carried out.

\section{Results and Analysis}

The results of the univariate data analysis illustrate the mean and standard deviation of the research variables, while the bivariate test analysis was carried out to analyze the effect of reproductive health exercise on hemoglobin levels using a parametric test. Bivariate and correlation tests were carried out if the data were normally distributed and homogeneous with values ( $p$ value $>0.05)$.

a. Univariate Analysis: The data normality test used the Shapiro Wilk method because the sample size was less than 50 respondents, in this study the number of respondents was 20 people or 10 people in each group. The data is said to be normally distributed if the $\mathrm{p}$-value is $>0.05$.

1. Test for normality of hemoglobin levels: The results of the normality test of hemoglobin levels before the intervention, during menstruation and after the intervention were given reproductive health exercise and $\mathrm{Fe}$ tablets in the intervention and control groups can be shown in Table 1 .

Table 1 Normality Test of Hemoglobin Levels

\begin{tabular}{|c|c|c|c|c|c|}
\hline No. & Variable & & $\mathbf{n}$ & Statistic & Sig. \\
\hline \multirow{3}{*}{1} & \multirow{3}{*}{ Group Intervention } & Pre gymnastics & \multirow{3}{*}{10} & 0,96 & 0,82 \\
\hline & & During menstruation & & 0,96 & 0,86 \\
\hline & & Post gymnastics & & 0,95 & 0,72 \\
\hline \multirow{3}{*}{2} & \multirow{3}{*}{ Group Control } & Pre administration of iron tablets & \multirow{3}{*}{10} & 0,87 & 0,1 \\
\hline & & During menstruation & & 0,86 & 0,07 \\
\hline & & Post administration of iron tablets & & 0,94 & 0,62 \\
\hline
\end{tabular}

Shapiro Wilk: Significant $>0.05$

Table 1 shows that all significant values are $>0.05$, which means that the data of hemoglobin levels before and after treatment and hemoglobin levels before and after menstruation in the intervention and control groups were normally distributed.

2. Homogeneity test: The results of the homogeneity test of hemoglobin levels before the intervention, during menstruation and after the intervention were given reproductive health exercise and Fe tablets in the intervention group can be shown in Table 2.
Table 2 Homogeneity Test of Hemoglobin Levels

\begin{tabular}{|c|l|l|c|c|}
\hline No. & Variable & n & Sig. \\
\hline \multirow{2}{*}{1} & \multirow{2}{*}{$\begin{array}{l}\text { Hemoglobin } \\
\text { Levels }\end{array}$} & Pre gymnastics & & 0,05 \\
\cline { 5 - 5 } & During menstruation & 0,73 \\
\cline { 5 - 5 } & Post gymnastics & & 0,014 \\
\hline
\end{tabular}

Test Homogeneity of Variances : significant $>0.05$

Table 2 shows that the significant value of hemoglobin levels in the intervention group before treatment is 0.05 and when menstruation is 0.73 , which 
means that the data is homogeneous, while the significant value after treatment is 0.014 which means that it is not homogeneous because it is smaller than the value 0.05 .

\section{b. Bivariate Analysis:}

1. Differences in hemoglobin levels before and during menstruation in the intervention group and the control group: The difference in hemoglobin levels before and during menstruation in the intervention group (giving reproductive health exercises and $\mathrm{Fe}$ tablets) and the control group (giving Fe tablets) can be shown in table 3.

Table 3 Differences in hemoglobin levels before and during menstruation in the intervention group and the control group

\begin{tabular}{|c|c|c|c|c|c|c|c|}
\hline No & Variable & Intervension & $\mathbf{n}$ & Mean & SD & Difference Mean & p-value \\
\hline \multirow{2}{*}{1} & \multirow{2}{*}{$\begin{array}{l}\text { Group } \\
\text { Intervention }\end{array}$} & Pre gymnastics & \multirow{2}{*}{10} & 10,1 & 0,75 & \multirow{2}{*}{1,7} & \multirow{2}{*}{0,000} \\
\hline & & During menstruation & & 8,4 & 0,71 & & \\
\hline \multirow{2}{*}{2} & \multirow{2}{*}{ Group Control } & Pre administration of iron tablets & \multirow{2}{*}{10} & 9,8 & 0,41 & \multirow{2}{*}{1,3} & \multirow{2}{*}{0,000} \\
\hline & & During menstruation & & 8,5 & 0,56 & & \\
\hline
\end{tabular}

*P value: significant $<0.05$

Table 3 shows the results that in the intervention group the hemoglobin level before exercise was $10.1 \mathrm{gr} /$ $\mathrm{dL}$ and during menstruation was $8.4 \mathrm{gr} / \mathrm{dL}$ decreased by $1.7 \mathrm{gr} / \mathrm{dL}$, while in the control group the average before treatment was $9.8 \mathrm{~g} / \mathrm{dL}$ and when menstruation was 8.5 $\mathrm{g} / \mathrm{dL}$ and decreased by $1.3 \mathrm{~g} / \mathrm{dL}$ with a p-value of 0.000 , which means that there were differences in hemoglobin levels in the intervention and control groups before and after menstruation.
2. Differences in hemoglobin levels before and after treatment in the intervention and control groups: The difference in hemoglobin levels before and after treatment in the intervention group (giving reproductive health exercises and $\mathrm{Fe}$ tablets) and the control group (giving $\mathrm{Fe}$ tablets) can be shown in table 4 .

Table 4 Differences in Hemoglobin Levels Before and After Treatment in the Intervention and Control Groups

\begin{tabular}{|c|c|c|c|c|c|c|c|}
\hline No & Variable & Intervension & $\mathbf{n}$ & Mean & SD & Difference Mean & p-value \\
\hline \multirow{2}{*}{1} & \multirow{2}{*}{$\begin{array}{l}\text { Group } \\
\text { Intervention }\end{array}$} & Pre & \multirow{2}{*}{10} & 10,1 & 0,75 & \multirow{2}{*}{2,9} & \multirow{2}{*}{0,000} \\
\hline & & Post & & 13 & 0,67 & & \\
\hline \multirow{2}{*}{2} & \multirow{2}{*}{ Group Control } & Pre & \multirow{2}{*}{10} & 9,8 & 0,41 & \multirow{2}{*}{2,4} & \multirow{2}{*}{0,000} \\
\hline & & Post & & 12,2 & 0,24 & & \\
\hline
\end{tabular}

$*$ P value: significant $<0.05$

Table 4 shows the results that in the intervention group the hemoglobin level before treatment was 10.1 $\mathrm{gr} / \mathrm{dL}$ and after treatment $13 \mathrm{~g} / \mathrm{dL}$ there was an increase of $2.9 \mathrm{~g} / \mathrm{dL}$, while in the control group the average before treatment was $9.8 \mathrm{gr} / \mathrm{dL}$. and after treatment 12.2 $\mathrm{g} / \mathrm{dL}$ and an increase of $2.4 \mathrm{~g} / \mathrm{dL}$ with a $\mathrm{p}$-value of 0.000 , which means that there are differences in hemoglobin levels in the intervention and control groups before and after treatment.

3. Differences in hemoglobin levels before treatment between the intervention and control groups: The difference in hemoglobin levels before treatment in the intervention group (giving reproductive health exercise and $\mathrm{Fe}$ tablets) and the control group (giving Fe tablets) can be shown in table 5 . 
Table 5 Differences in pre-treatment hemoglobin levels between the intervention and control groups.

\begin{tabular}{|c|l|c|c|c|c|}
\hline No . & Variable & Mean & SD & Difference Mean & p-value \\
\hline 1 & Group Intervention & 10,1 & 0,75 & \multirow{2}{*}{0,3} & \multirow{2}{*}{0,05} \\
\hline 2 & Group Control & 9,8 & 0,41 & & \\
\hline
\end{tabular}

*P value: significant $<0.05$

Table 5 shows the results that the average hemoglobin level before being given treatment in the intervention group was $10.1 \mathrm{gr} / \mathrm{dL}$ and in the control group an average of $9.8 \mathrm{~g} / \mathrm{dL}$ with an average difference of $0.3 \mathrm{gr} / \mathrm{dL}$ and $\mathrm{p}$-value. value $=0.05$, which means that there is a difference in the mean $\mathrm{Hb}$ of blood between the intervention group and the control group.
4. Differences in menstrual hemoglobin levels between the intervention and control groups: Differences in hemoglobin levels during menstruation in the intervention group (giving reproductive health exercises and Fe tablets) and the control group (giving $\mathrm{Fe}$ tablets) can be shown in table 6 .

Table 6 Differences in menstrual hemoglobin levels between the intervention and control groups

\begin{tabular}{|c|l|c|c|c|c|}
\hline No. & Variable & Mean & SD & Difference Mean & p-value \\
\hline 1 & Group Intervention & 8,4 & 0,71 & \multirow{2}{*}{0.0 .1} & \multirow{2}{*}{0,73} \\
\hline 2 & Group Control & 8,5 & 0,56 & & \\
\hline
\end{tabular}

$*$ P value: significant $<0.05$

Table 6 shows the results that the average hemoglobin level during menstruation was given treatment in the intervention group $8.4 \mathrm{~g} / \mathrm{dL}$ and in the control group an average of $8.5 \mathrm{~g} / \mathrm{dL}$ with a mean difference of $-0.1 \mathrm{gr} / \mathrm{dL}$ and p-value. value 0.73 means that there is no difference in the mean hemoglobin levels during menstruation between the intervention and control groups.
5. Differences in hemoglobin levels after treatment between intervention and control groups: The differences in hemoglobin levels after treatment in the intervention group (presenting health sessions and Fe tablets) and groups (presenting Fe tablets) can be shown in table 7.

Table 7 Differences in hemoglobin levels after treatment between intervention and control groups

\begin{tabular}{|c|l|c|c|c|c|}
\hline No. & Variable & Mean & SD & Difference Mean & p-value \\
\hline 1 & Group Intervention & 13 & 0,67 & \multirow{2}{*}{0,8} & 0,014 \\
\hline 2 & Group Control & 12,2 & 0,24 & & \\
\hline
\end{tabular}

$*$ P value: significant $<0.05$

Table 7 shows the results that the average hemoglobin level after being given treatment in the intervention group was $13 \mathrm{~g} / \mathrm{dL}$ and in the control group an average of $12.2 \mathrm{~g} / \mathrm{dL}$ with an average difference of $0.8 \mathrm{gr} / \mathrm{dL}$ and a $\mathrm{p}$-value of 0.014 ., meaning that there is a difference in mean hemoglobin levels between the intervention and control groups.

\section{Discussion}

This study was conducted on 20 anemia adolescents who were divided into 2 groups, 10 anemia adolescents in the intervention group who were given reproductive health exercise with $\mathrm{Fe}$ tablets and 10 anemia adolescents in the control group who were given Fe tablets alone for 4 weeks to see their hemoglobin levels. In the intervention 
and control groups, hemoglobin levels were checked before being given reproductive health exercise and $\mathrm{Fe}$ tablets for the intervention group and Fe tablets for the control group for 4 weeks. After 4 weeks of treatment, re-examination was carried out in the intervention and control groups.

Based on the results of the t-test dependent statistical test, it shows that there is a difference between the hemoglobin levels before and after treatment in the intervention and control groups. After being given treatment to the intervention group (giving reproductive health exercises and $\mathrm{Fe}$ tablets), the respondents experienced an average increase in hemoglobin levels by $2.9 \mathrm{~g} / \mathrm{dL}$ and the control group (giving Fe tablets) the respondents experienced an average increase in hemoglobin levels by $2.4 \mathrm{gr} / \mathrm{dL}$. The difference in the change in the mean difference in hemoglobin levels between the intervention and control groups which has a p-value of 0,000 means that there are differences in the mean difference in hemoglobin levels in the intervention group and the control group.

This research is in line with the results of research conducted by Sarah et al., (2019) concerning the effect of reproductive health exercise on adolescent hemoglobin levels at SMP 26 Semarang in 2019 which were divided into 2 groups, namely the intervention group and the control group. Results in the intervention group that was carried out for 4 weeks with iron tablets and reproductive health exercises with a duration of 1520 minutes for 3 times a week. There was an increase in hemoglobin levels from an average of $10.43 \mathrm{gr} / \mathrm{dL}$ to $13.98 \mathrm{gr} / \mathrm{dL}$, thus the effect of reproductive health exercise on adolescent hemoglobin levels at SMP 26 Semarang in 2019.

In addition to reproductive health training, this is in line with research conducted by Setyaningrum et $\mathrm{al}^{17}$, namely aerobic exercise in the morning and evening to increase blood hemoglobin levels at SMK Muhammadiyah and SMP Kradenan Blora. Based on the results of research that did aerobic exercise in the morning before being given treatment, the hemoglobin level was $11.90 \mathrm{gr} \%$ (early adolescents) then increased to $13.2 \mathrm{gr} \%$ and $12.20 \mathrm{gr} \%$ (late adolescents) increased to $12.70 \mathrm{gr} \%$. Exercises carried out at night before being given treatment had a hemoglobin level of $12.20 \mathrm{gr} \%$ (early adolescents) increased to $13.60 \mathrm{gr} \%$ and $12.30 \mathrm{gr} \%$ (late adolescents) increased to $13.10 \mathrm{gr} \%$, it can be concluded that there was a difference in hemoglobin levels before and after giving gymnastics to adolescents.
According to Kumalasari ${ }^{4}$ Teenage girls who have experienced menstruation are at high risk of anemia, especially iron nutritional anemia, this is because young women bleed every month and consume less iron intake which causes an increase in iron expenditure so that iron levels in the blood decrease and can trigger anemia. ${ }^{20}$ During menstruation, women lose $\leq 1.0 \mathrm{mg}$ or lose $28 \mathrm{mg}$. The iron that women need when they are not menstruating is 1000 calories of food containing 6 grams of iron, while during menstruation women need iron consumption of $18 \mathrm{mg} /$ day. Efforts that can be made to overcome anemia in adolescent girls are by giving Blood Supplement Tablets with a given dose of 1 tablet/week and 1 tablet/day during menstruation (KEMENKES), Blood added tablets are iron tablets that contain $200 \mathrm{mg}$ of ferrous sulfate or $60 \mathrm{mg}$ of elemental iron and 0.25 $\mathrm{mg}$ of folic acid in each tablet.

Apart from giving blood supplement tablets to adolescents. According to Nurafandi, one strategy that can be done to overcome the problem of anemia in adolescents is by providing therapy in the form of physical activity. Doing physical activity can increase blood volume caused by cardiovascular changes. Individuals who exercise regularly will experience a slight increase in hemoglobin, this is because cells or tissues need more $\mathrm{O} 2$ (oxygen) when doing activities ${ }^{17}$.

Increased oxygen consumption during physical activity allows hemoglobin which carries protein in erythrocytes to reach cells. An important function of hemoglobin is as a medium for transporting oxygen from the lungs (respiratory organs) throughout the body. Physical activity is an activity that can improve health status if it is done regularly, routinely and repeatedly. Physical activity that is in great demand by young women is gymnastics ${ }^{21}$.

Reproductive health exercises that are carried out regularly can stretch muscles so that an increase in metabolic activity increases blood circulation and activates the parasympathetic nerves which causes blood vasodilation, resulting in large oxygen concentrations, in the presence of large oxygen in the body, changes in intramuscular osmotic pressure can occur which encourages vascular compartment to the interstitial space which causes plasma volume to decrease so that red blood cells recompile and increase the transfer of iron from the bone marrow to red blood. So that these cells produce an increase in hemoglobin production ${ }^{22-27}$ 


\section{Conclusion and Recommendation}

Based on the results of the research and the discussion that has been described, the conclusions in this study are that reproductive health exercise affects the hemoglobin levels of adolescent girls. Provision of reproductive health exercise can increase hemoglobin levels for adolescents who have anemia and can be an effort to overcome anemia in addition to giving blood added tablets, physical activity for reproductive health exercises can be used as an alternative in the treatment of anemia in adolescent girls, because exercise is one of them. Physical activity that many adolescents like.

Ethical Clearance: Taken from Poltekkes Kemenkes Sorong Ethical committee.

Source of Funding: Poltekkes Kemenkes Sorong

\section{Conflict of Interest: Nil.}

\section{References}

1. Citrawathi, Desak Made. SISTEM REPRODUKSI MANUSIA. GRAHA ILMU:Yogyakarta. 2014

2. Rupali, P. A., \& Sanjay, K. S. 2015. Anemia:

Does it Have Effect on Menstruation? Scholars Journal of Applied Medical Sciences (SJAMS), 3, 514517. Retrieved from http:/Www.saspublisher.com/

3. Birawida, A.B., Selomo, M., Mallongi, A. Potential hazards from hygiene, sanitation and bacterium of refill drinking water at Barrang Lompo island (water and food safety perspective) IOP Conference Series: Earth and Environmental Science 2018; Volume 157, Issue 1

4. Kumalasari, D., Kameliawati, F., Mukhlis, H., \& Kristanti, D. A. Pola Menstruasi dengan Kejadian Anemia pada Remaja Desi. 2019; 1, 187-192.

5. Russeng, S.S., Saleh, L.M., Virani, D., Latief, A.W.L., Mallongi, A. The investigation of the lactic acid change among employee of national electrical power plan. Indian Journal of Public Health Research and Development 2018; Volume 9, Issue 1, Pages 361-365

6. Amqam, H., Thalib, D., Anwar, D., Sirajuddin, S., Mallongi, A. Human health risk assessment of heavy metals via consumption of fish from Kao Bay. Reviews on Environmental Health. 2020; https://doi.org/10.1515/reveh-2020-0023

7. Mallongi, A., Daud, A., Ishak, H., La Ane, R., Birawida, A.B., Ibrahim, E., Selomo, M., Rahman,
S.A. Clean water treatment technology with an upflow slow sand filtration system from a well water source in the tallo district of Makassar. Journal of Environmental Science and Technology, 2017; Volume 10, Issue 1, Pages 44-48

8. Hasmi, Mallongi, A. Health risk analysis of lead exposure from fish consumption among communities along Youtefa Gulf, Jayapura. Pakistan Journal of Nutrition 2016; Volume 15, Issue 10, 15 September Pages 929-935

9. World Health Organization (WHO), Haemoglobin Concentrations for The Diagnosis of Anaemia and Assessment of Severity. Vitamin and mineral Nutrition Information System. Geneva: WHO 2014.. Di unduh dari www.who.int/vmnis/ indicators/haemo- globin.pdf. Tanggal 15 Februari 2020

10. Riskesdas. Riset kesehatan Dasar Laporan Nasional 2018. Jakarta: BPPK. 2019.

11. KEMENKES, R. PROFIL KESEHATAN 2017. In Ministry of Health Indonesia. Retrieved from website: http://www.kemkes.go.id

12. Kayame, R., Mallongi, A. Relationships between smoking habits and the hypertension occurrence among the adults of communities in paniai regency, Papua Indonesia. Indian Journal of Public Health Research and Development 2018; Volume 9, Issue 1, Pages 332-336

13. Endah Yani, R.W., Mallongi, A., Andarini, S., Prijatmoko, D., Dewanti, I.R. The effect of zinc saliva on the toddlers' nutritional status. Journal of International Dental and Medical Research, 2016, Volume 9, Issue 1, Pages 29-32

14. Syam, A., Palutturi, S., Djafar, N., Budu, Astuti, N., Thaha, A.R. Micronutrients, academic performance and concentration of study: A literature review. International Journal of Applied Business and Economic Research, 2016; Volume 14, Issue 5, 2016, Pages 2831-2843

15. Nurafandi, M. Perbandingan Kadar Hemoglobin Terhadap Latihan Aerobik Pagi Dan Malam Hari Pada Tim Futsal Santri PPTQ Bukit Baruga Kota Makassar. Jurnal Keolahragaan.2017.

16. Setiyawan, \& Windyastuti, E. Pengaruh Jus Buah Kurma Terhadap Kadar Hemoglobin Dan Jumlah Sel Darah Pada Pasien Kanker Paru Dengan Kemoterapi. Profesi (Profesional Islam) : Media Publikasi Penelitian, 2018;. 15(2), 18. https://doi. 
org/10.26576/profesi.249

17. Setyaningrum, A. D. W., Sugiyanto, \& Rachma, N. Pengaruh Latihan Senam Pagi dan Malam terhadap Peningkatan Kadar Hemoglobin Darah pada Remaja Putri.2019.;9(4), 380-387.

18. Denis, R. S., \& Conway, J. L. Iron deficiency and aerobic endurance performance in a female club runner Carence en fer et performance aérobie chez une coureuse de. Science \& amp; Sports, 2018.; $34(1), 45-51$.

https://doi.org/10.1016/j.scispo.2018.04.012

19. Fitria, Sarah Sri, $\mathrm{Rr}$ Pujiastuti, Endang Mulyantoro, Donny K. Implementation of Reproductive Health Gymnastics Against Female Adolescents Hemoglobin Level. E3SWebofConferences12504009 ICENIS 2019

20. Sholica, C. A., \& Muniroh, L. HUBUNGAN ASUPAN ZAT BESI, PROTEIN, VITAMIN C DAN POLA MENSTRUASI DENGAN KADAR HEMOGLOBIN PADA REMAJA PUTRI. Media Gizi Indonesia, 2019.; 14(2), 147-153. Retrieved from https://doi.org/10.204736/mgi.v14i2.

21. Ibaneza, G. B.-, Sánchezb, A. S., Ramos-Pẽnafiela, C. O., \& A. Iron deficiency anaemia. 2016;79(2), 88-97.

22. Bril, V., Malik, R. A., \& Perkins, B. A. Significant Dose-Response Relationship Between Exercise Adherence and Hemoglobin A1C Change for Aerobic Training but Not Resistance or
Combined Training. Canadian Journal of Diabetes, 2018.; 42(5), S10. https://doi.org/10.1016/j. jcjd.2018.08.031

23. Data Rekam Medik Puskesmas Sowi Tahun 2020.

24. Gilchrist, J. D., Pila, E., Castonguay, A., Sabiston, C. M., \& Mack, D. E. Body pride and physical activity : Differential associations between fitnessand appearance-related pride in young adult Canadians. Body Image, 2018.; 27, 77-85. https:// doi.org/10.1016/j.bodyim.2018.08.010

25. Mallongi, A., Indra, R., Arief, M.U., Fais Satrianegara, M., Environmental pollution and health problems due to forest fires with $\mathrm{CO}_{2}$ parameters., Medico-Legal Update Volume 20, Issue 3, July-September 2020, Pages 888-892.

26. Masriadi, Azis, R.,Sumantri, E., Mallongi, A., Effectiveness of non pharmacologic therapy through surveillance approach to blood pressure degradation in primary hypertension patients, Indonesia., Indian Journal of Public Health Research and Development. Volume 9, Issue 4, April 2018, Pages 249-255

27. Posmaningsih, D.A., Aryasih, G.A.M., Hadi, M.C., Marwati, N.M., Mallongi, A. The influence of media booklet in behavior change of waste management in elementary school students, South Denpasar, Bali., Indian Journal of Public Health Research and Development. Volume 9, Issue 8, August 2018, Pages 1506-1511 